\title{
Powdery Mildew Disease Identification in Karpoori Variety of Betel Vine Plants using Histogram Based Techniques
}

\author{
${ }^{1}$ J.Vijayakumar and ${ }^{2} \mathrm{Dr}$. S.Arumugam \\ ${ }^{1} A S P / E C E$, Nandha College of Technology, Erode, Tamil nadu, India. \\ ${ }^{2}$ Principal, Nandha Engineering College, Erode, Tamil nadu, India. \\ vijiece@yahoo.co.in; arumugamdote@yahoo.co.in
}

\begin{abstract}
The betel vine cultivation is very much affected by diseases and outcome of the farmer is big loss for betel vine cultivation. The aim of this paper is to detection of Powdery mildew disease in the betel vine plants using histogram based digital image processing techniques. The digital images of the uninfected or normal betel vine leaves and the digital images of the infected in powdery mildew diseased betel vine leaves at different stages are collected from different betel vine plants using a high resolution digital camera and collected betel vine images are stored with JPEG format. The digital image analyses of the leaves are done using the image processing toolbox in MATLAB. The RGB color betel vine images were converted into gray scale image. Histogram were plotted and stored as a database for uninfected and powdery mildew disease infected in first day to final day for all the Karpoori variety of betel vine leaves. Finally this investigation helps to recognize the powdery mildew disease can be identified before it spreads to entire crop.
\end{abstract}

Keywords: Piperaceae; Piper betel; Powdery Mildew disease; Oidium Piperis

\section{Introduction}

The betel vine leaves were popularly known as Vettilai in Tamil and also commonly known as Paan in Hindi. Biological name of betel vine leaves were known as Piper betel. It belongs to the family of Piperaceae. The Vitamins $B$ and $C$ is highly available in the betel vine leaves and they were mainly used in a tonic to the brain, liver and heart for human [95]. The fresh juice of betel vine leaves are used to many ayurvedic preparations. The betel vine plants were cultivated throughout India except the dry northwestern parts. The six betel vine leaves with a little bit of slaked lime are equal to $300 \mathrm{ml}$ of cow milk particularly for the vitamin and mineral nutrition. The group of research work was going on in the field of betel vine disease analysis for various centers within the country under the name "All India Coordinated Research Project on Betel vine". 70 varieties of betel vine leaves are Cultivated in the world. Among these 70 varieties, 40 varieties of betel vine leaves are Cultivated in India. 30 varieties of betel vine leaves are Cultivated in West Bengal. Tamil Nadu, Uttar Pradesh, Bihar, Maharashtra, Karnataka, West Bengal, Andhra Pradesh and Kerala states are widely cultivated in the betel vine. In Tamilnadu, based on the color, size and taste, there are many varieties of betel vine leaves available and some of the most popular varieties are vellaikodi, Karpoori, pachaikodi and Sirugamani. Karpoori variety of betel vine leaves was considered in this research work paper. During the cultivation of betel vine, diseases were one of the most important causes that reduce quantity of the betel vine leaves. The most important betel vine plants diseases were powdery mildew disease, leaf rot disease, foot rot disease and leaf spot disease. 
Powdery mildew disease is caused by Oidium piperis. The disease appears on the undersurface of the leaves as white to brown powdery patches. These patches gradually increase in size and often coalesce with each other. They vary in size from a few to $40 \mathrm{~mm}$ in diameter and are covered by dusty growth which is fairly thick in cases of severe attack [95][96]. Areas on the upper surface corresponding to patches on the under surface appear yellowish, raised and irregular in outline. Young leaves when infected fail to grow and become deformed the surface being cracked and the margin turned inwards. The disease has been reported to be in the leaves only and it has been found to
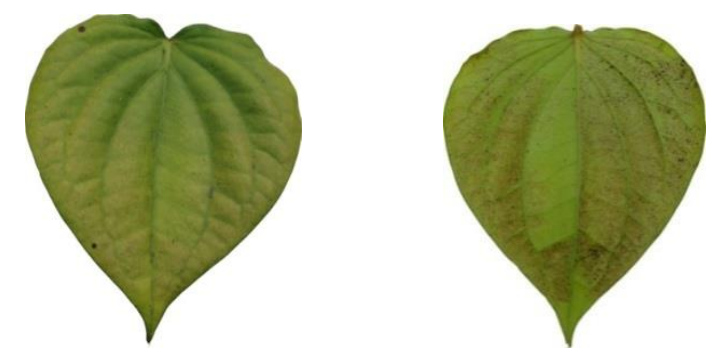

Figure 1. Powdery mildew disease affected betel vine leaves

disappear during the hot season. Figure 1 shows the images of front and back view of powdery mildew infected betel vine leaves. In this research paper Powdery mildew disease were considered for Karpoori variety of betel vine plants.

\section{Materials and Methods}

For the Histogram based analysis, the front and back view normal or healthy betel vine leaves and powdery mildew disease infected in early stage to final stage betel vine leaves were individually collected at different plants using a high-resolution digital camera for all Karpoori betel vine plants from erode, karur and trichy district of Tamil nadu, India. The collected betel vine leaves back grounds were eliminated using photo shop and these digital images were stored in the system [103]. These stored betel vine images were resized. Digital imaging techniques were divided into two phases. Normal or uninfected betel vine leaves phase and Powdery mildew disease infected in early stage to final stage of betel vine leaves phase. The uninfected betel vine leaves phase consists of without any disease infected in the betel vine leaves. The same variety of front and back view betel vine leaves were collected at different betel vine plants and place. The RGB color betel vine images were converted into gray scale image. Histogram were plotted and stored as a database for all Karpoori variety of betel vine leaves.

Infected betel vine leaves phase consists of Powdery mildew disease infected in early stage to final stage of betel vine leaves. The same varieties of betel vine sample leaves were selected from uninfected betel vine plant, which is nearest to the betel vine plant infected by Powdery mildew disease. The serial numbers were given to all selected betel vine sample leaves. The front and back view betel vine sample leaves was collected serial number wise at different plants and place. The RGB color betel vine images were converted into gray scale image. Histogram was plotted for all Karpoori variety of betel vine leaves and plotted histogram were compared with the stored data base values. If the calculated Histogram plot and stored Histogram plot were same range for all gray scale values, the selected betel vine leaves were included in samples otherwise samples were removed to the selected list. 
The accepted same variety of betel vine sample leaves were collected serial number wise for next two three days. The RGB color betel vine images were converted into gray scale image. Histogram was plotted for all Karpoori variety of betel vine leaves and plotted histogram were compared with the stored data base values. If any difference were identified between calculated and stored database values on any particular day for the particular betel vine leaf, that particular day were counted as Powdery mildew disease infected in first day for the particular betel vine sample leaf. These Powdery mildew disease infected betel vine leaves were collected serial number wise for infected in first day to final day. The RGB color betel vine images were converted into gray scale image. Histogram was plotted for all Karpoori variety of betel vine leaves and plotted histogram were stored data base values.

\section{Result}

The histogram for front and back view normal betel vine leaves was shown in figure 2.The histogram for front and back view powdery mildew disease infected in first day betel vine leaves were shown in figure 3.The histogram for front and back view powdery mildew disease infected in second day betel vine leaves were shown in figure 4. The histogram for front and back view powdery mildew disease infected in third day betel vine leaves were shown in figure 5.The histogram for front and back view powdery mildew disease infected in fourth day betel vine leaves were shown in figure 6.The histogram for front and back view powdery mildew disease infected in fifth day betel vine leaves were shown in figure 7.

The gray scale value of the histogram for front view of uninfected betel vine leaf was between 100 and 250. However the initial gray scale value was near to 100 . Final gray scale value was near to 200 . Maximum frequency of occurrence of the gray scale value was between 150 and 200.The gray scale value of the histogram for back view of uninfected betel vine leaf was between 150 and 250 . However the initial gray scale value was near to 150 . Final gray scale value was near to 250 . The maximum frequency of occurrence of the gray scale value was near to 200.The gray scale value of the histogram for front view of betel vine leaf with powdery mildew disease at first day of infection was between 50 and 200. However the initial gray scale value was near to 100 and final gray scale value was near to 150.

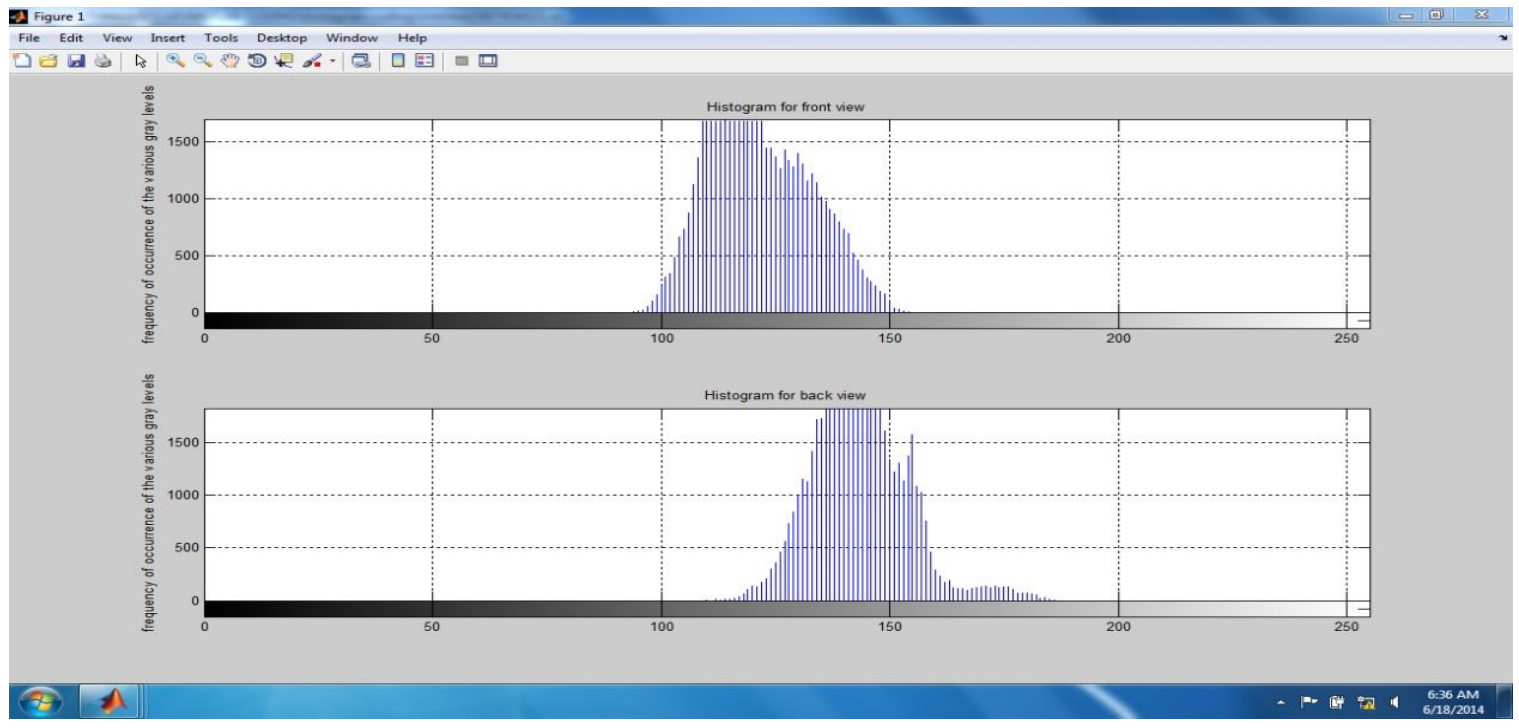

Figure 2. Histogram for front and back view normal betel vine leaves 


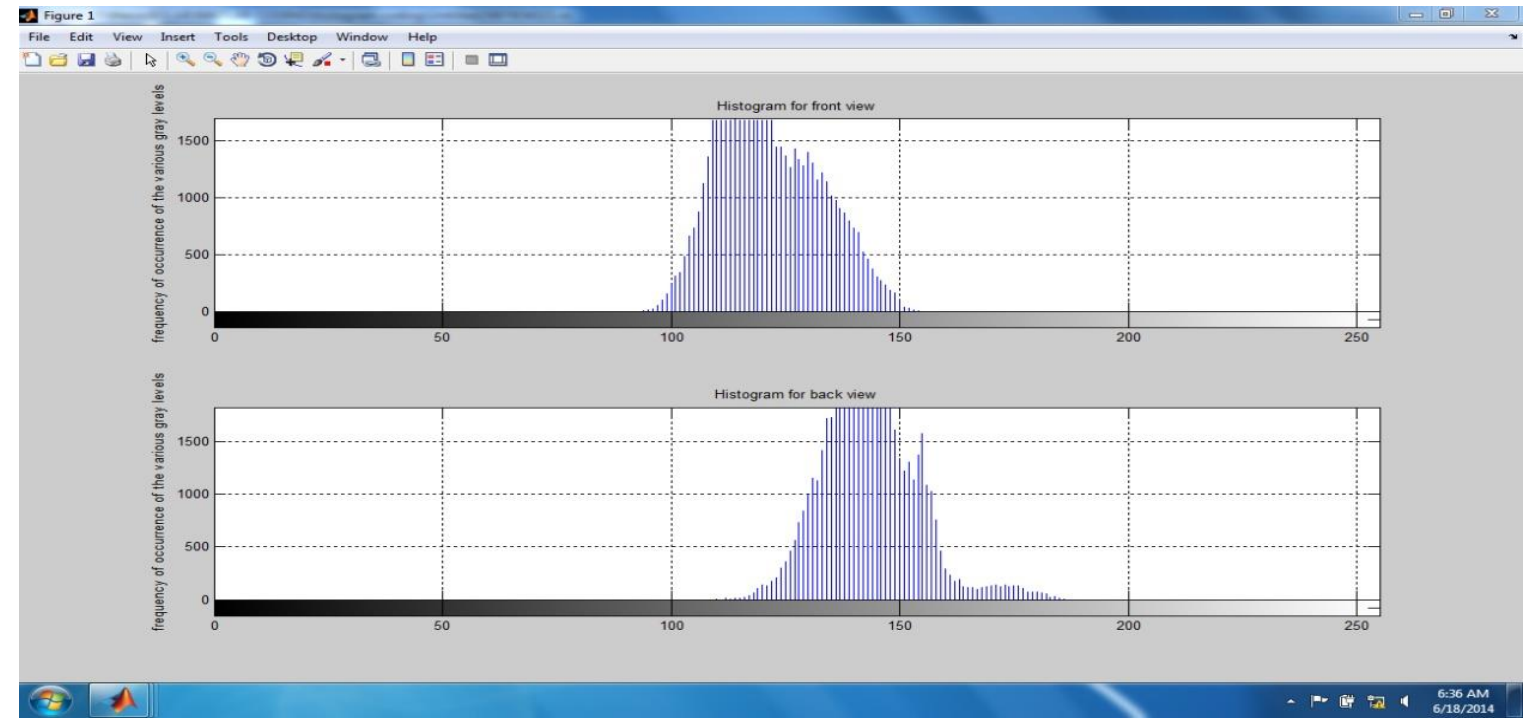

Figure 3. Histogram for front and back view powdery mildew disease infected in first day betel vine leaves

Maximum frequency of occurrence of the gray scale value was between 100 and 150 .The gray scale value of the histogram for back view of betel vine leaf with powdery mildew disease at first day of infection was between 100 and 200. However the initial gray scale value was near to 100 and final gray scale value was near to 150 . Maximum frequency of occurrence of the gray scale value was near to 150.The gray scale value of the histogram for front view of betel vine leaf with powdery mildew disease at second day of infection was between 0 and 150. However the initial gray scale value was near to 50 and final gray scale value was near to 150. Maximum frequency of occurrence of the gray scale value was near to 100 .The gray scale value of the histogram for

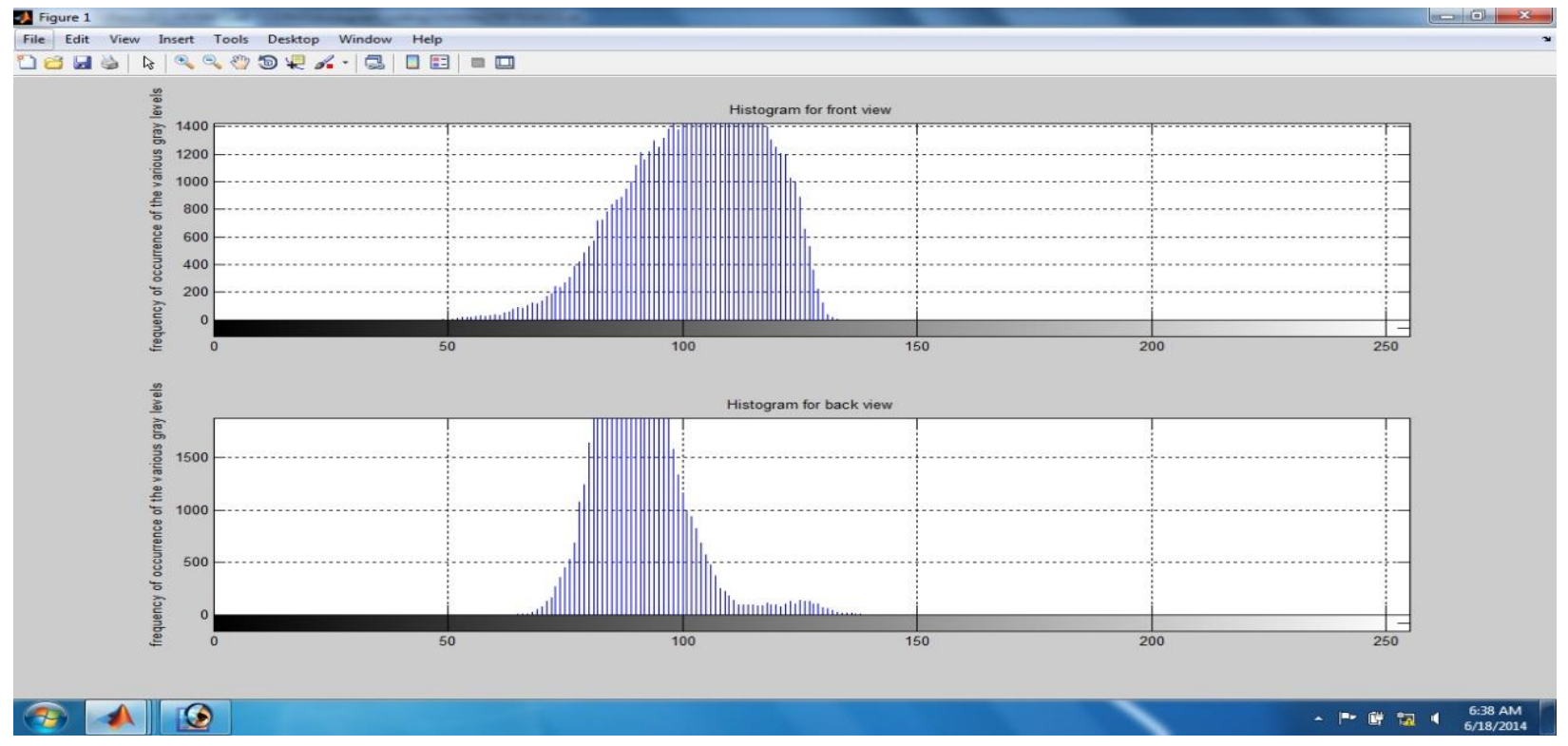

Figure 4. Histogram for front and back view powdery mildew disease infected in second day betel vine leaves 


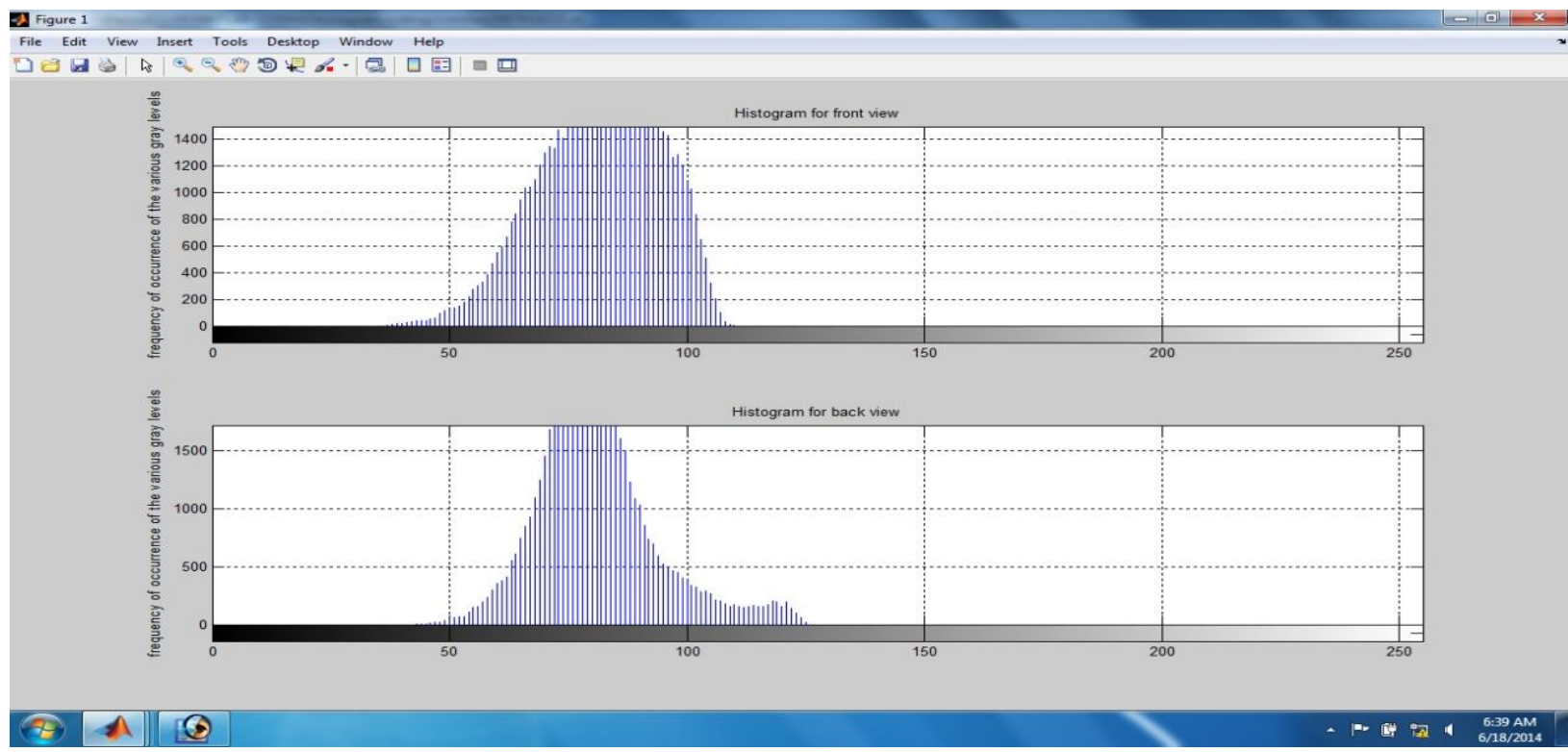

Figure 5. Histogram for front and back view powdery mildew disease infected in third day betel vine leaves

back view of betel vine leaf with powdery mildew disease at second day of infection was between 50 and 150. However the initial gray scale value was near to 50 and final gray scale value was near to 150. Maximum frequency of occurrence of the gray scale value was near to 100 . The gray scale value of the histogram for front view of betel vine leaf with powdery mildew disease at third day of infection was between 0 and 150. However the initial gray scale value was near to 50 and final gray scale value was near to 100 . Maximum frequency of occurrence of the gray scale value was between 50 and 100.The gray scale value of the histogram for back view of betel vine leaf with powdery mildew disease at third day of infection was between 50 and 150. However the initial gray scale value was near to 50 and final gray scale value was between 100 and 150 .

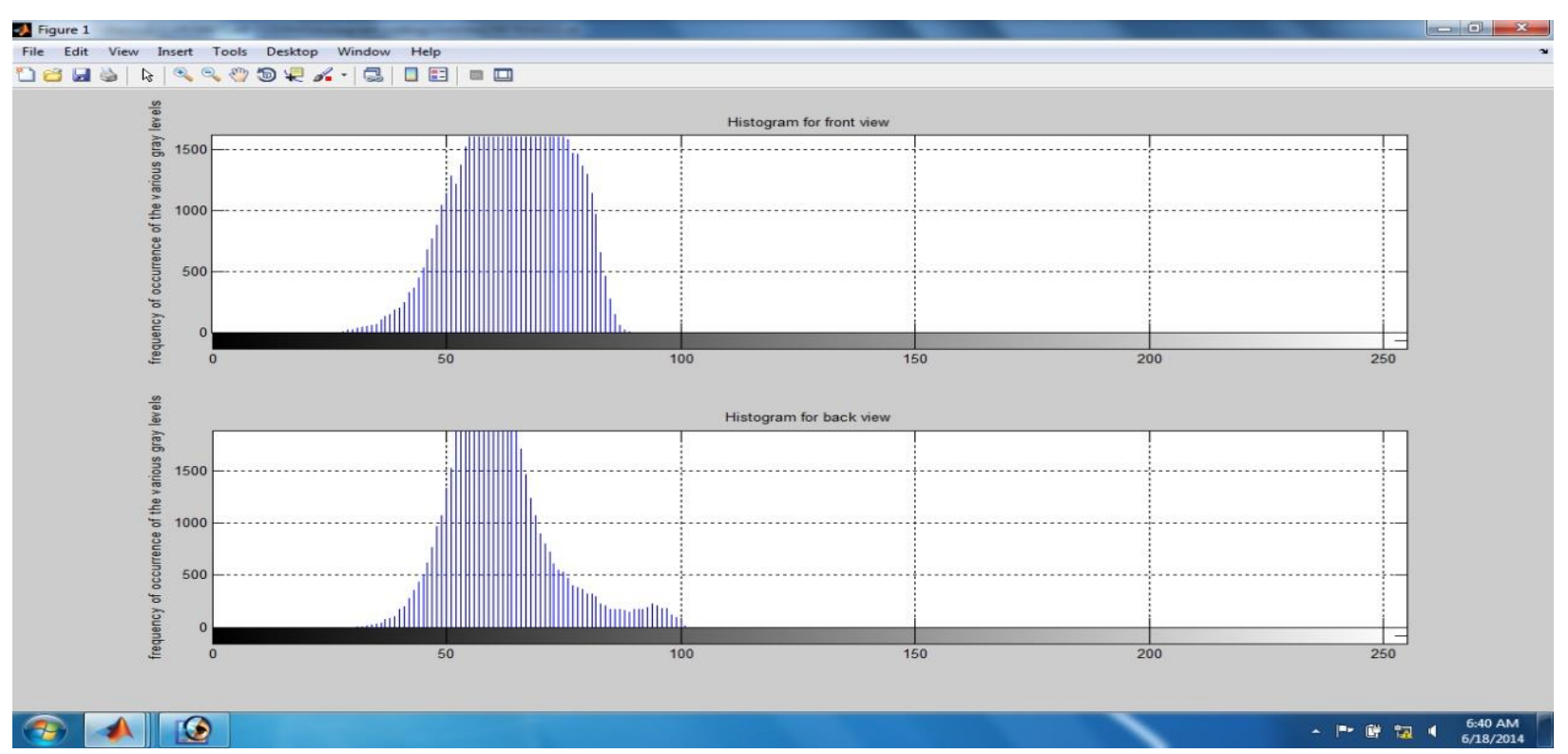

Figure 6. Histogram for front and back view foot rot disease infected in fourth day betel vine leaves 


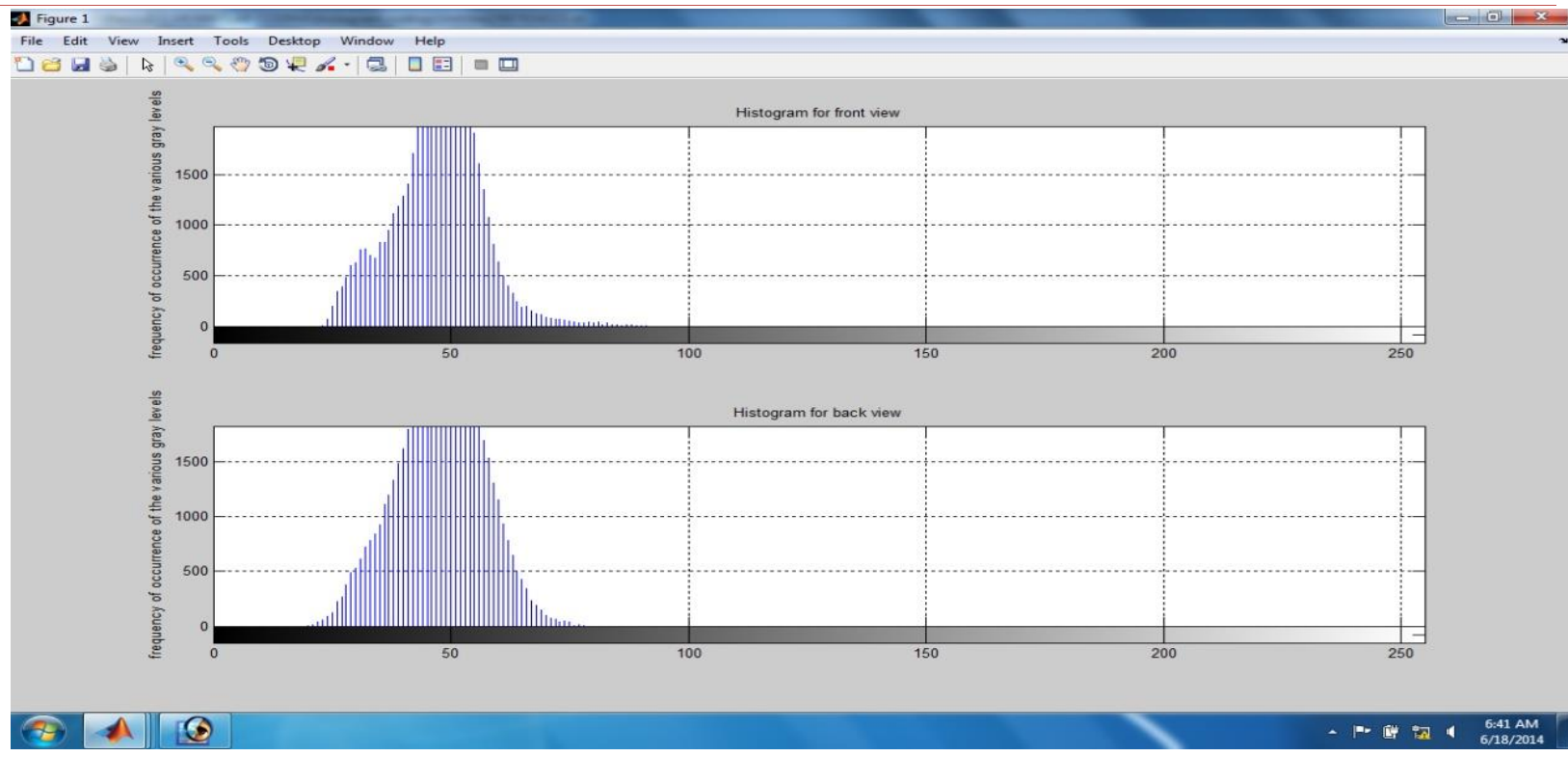

Figure 7. Histogram for front and back view powdery mildew disease infected in fifth day betel vine leaves

Maximum frequency of occurrence of the gray scale value was between 50 and 100 .The gray scale value of the histogram for front view of betel vine leaf with powdery mildew disease at fourth day of infection was between 50 and 100. However the initial gray scale value was between 0 and 50 and final gray scale value was near to 100 . Maximum frequency of occurrence of the gray scale value was between 50 and 100.The gray scale value of the histogram for back view of betel vine leaf with powdery mildew disease at fourth day of infection was between 50 and 100. However the initial gray scale value was between 0 and 50 and final gray scale value was 100. Maximum frequency of occurrence of the gray scale value was near to 50.The gray scale value of the histogram for front view of betel vine leaf with powdery mildew disease at fifth day of infection was between 0 and 100 . However the initial gray scale value was between 0 and 50 and final gray scale value was near to 100 . Maximum frequency of occurrence of the gray scale value was near to 50.The gray scale value of the histogram for back view of betel vine leaf with powdery mildew disease at fifth day of infection was between 0 and 100. However the initial gray scale value was between 0 and 50 and final gray scale value was near to 100 . Maximum frequency of occurrence of the gray scale value was near to 50 .

\section{Conclusion}

The above research techniques express that the karpoori variety of betel vine plants Oidium piperis fungus can be recognized in starting stage of betel vine plantation and saved before the Oidium piperis fungus starts to reach complete karpoori variety of betel vine crop. The method of detecting the Oidium piperis fungus cost is effective. This technique can also be extended to detect fungus or diseases of all kind plants to recognize starting stage preventive action.

\section{REFERENCES}

[1]. Alham F. Aji, Qorib Munajat, Ardhi P. Pratama, Hafizh Kalamullah, Aprinaldi, Jodi Setiyawan \& Aniati M. Arymurthy 2013, 'Detection of Palm Oil Leaf Disease with Image Processing and Neural etwork Classification on Mobile Device', International Journal of Computer Theory and Engineering, Vol.5, no.3, pp. 528-532. 
[2]. Ajay A. Gurjar, Viraj A. Gulhane 2011, 'Disease Detection on Cotton Leaves by Eigenfeature Regularization and Extraction Technique' International Journal of Electronics, Communication \& Soft Computing Science and Engineering, Vol.1, no.1, pp. 1-4.

[3]. Arunkumar Beyyala1 \& Sai Priya Beyyala 2012, 'Application for Diagnosis of Diseases In Crops Using Image Processing', International Journal of Life Sciences Biotechnology and Pharma Research, Vol.1, no.1, pp. $172-175$.

[4]. S. Ananthi \& S. Vishnu Varthini 2012, 'Detection and Classification of Plant Leaf Diseases', International Journal of Research in Engineering \& Applied Sciences, Vol.3, no.1, pp. 763 -773.

[5]. S. Arivazhagan, R. Newlin Shebiah, S. Ananthi \& S. Vishnu Varthini 2013, 'Detection of unhealthy region of plant leaves and classification of plant leaf diseases using texture features', Agricultural Engineering International: CIGR Journal, Vol.15, no.1, pp. 211 -217.

[6]. Anand.H.Kulkarni \& Ashwin Patil R. K 2012, 'Applying image processing technique to detect plant diseases', International Journal of Modern Engineering Research, Vol.2, no.5, pp. 3661 -3664.

[7]. Arti N. Rathod, Bhavesh Tanawal \& Vatsal Shah 2013, Image Processing Techniques for Detection of Leaf Disease', International Journal of Advanced Research in Computer Science and Software Engineering, Vol.3, no.11, pp. $397-399$.

[8]. Amina Khatra 2013, 'A Novel Machine Vision System for Identification of Yellow Rust in Wheat Plants', International Journal of Image Processing, Vol.7, no.5, pp.430-435.

[9]. Arun Kumar.T \& Karun Verma 2010, 'A Theory Based on Conversion of RGB image to Gray image', International Journal of Computer Applications, Vol.7, no.2, pp.7-9.

[10]. Alberto Tellaeche, Xavier P. Burgos-Artizzu, Gonzalo Pajares \& Angela Ribeiro 2008, 'Avision-based method for weeds identification through the Bayesian decision theory', The journal of the Pattern Recognition society, Vol.4, no.1, pp.521-530.

[11]. Amir Alipasandi, Hosein Ghaffari \& Saman Zohrabi Alibeyglu 2013, 'Classification of three Varieties of Peach Fruit Using Artificial Neural Network Assisted with Image Processing Techniques', International Journal of Agronomy and Plant Production, Vol.4, no.9, pp.2179-2186.

[12]. Al-Hiary.H, S. Bani-Ahmad, M. Reyalat, M. Braik \& Z. ALRahamneh 2011, 'Fast and Accurate Detection and Classification of Plant Diseases', International Journal of Computer Applications, Vol.17, no.1, pp. 31 - 38.

[13]. Ajit Danti, Manohar Madgi \& Basavaraj S. Anami 2012, 'Mean and Range Color Features Based Identification of Common Indian Leafy Vegetables', International Journal of Signal Processing, Image Processing and Pattern Recognition, Vol.5, no.3, pp. 151 - 160.

[14]. Anjali Verma, Nikhil Kumar \& S. A. Ranade 2004, 'Genetic diversity amongst landraces of a dioecious vegetatively propagated plant, betelvine (Piper betle L.)', Indian Academy of Sciences, Vol.29, no.3, pp. $319-328$.

[15]. Balamurugan.P \& R. Rajesh 2012, 'Neural Network Based System for the Classification of Leaf Rot Disease in Cocos Nucifera Tree Leaves', European Journal of Scientific Research, Vol.88, no.1, pp. 137 - 145.

[16]. Basavaraj S. Anami, Suvarna S. Nandyal \& A. Govardhan 2010, 'A Combined Color, Texture and Edge Features Based Approach for Identification and Classification of Indian Medicinal Plants', International Journal of Computer Applications, Vol.6, no.12, pp.45-51. 
J.Vijayakumar \& Dr. S.Arumugam; Powdery Mildew Disease Identification in Karpoori Variety of Betel vine Plants using Histogram Based Techniques, Advances in Image and Video Processing, Volume 2 No 5, Oct (2014); pp: $63-75$

[17]. Basvaraj .S. Anami, J.D. Pujari \& Rajesh.Yakkundimath 2011, Identification and Classification of Normal and Affected Agriculture/horticulture Produce Based on Combined Color and Texture Feature Extraction, Vol.1, no.3, pp. 356-360.

[18]. Balaji Kaveti, Lisa Tan, Sarnnia, Tan Sin Kuan \& Mirza Baig 2011, 'Antibacterial Activity Of Piper Betel Leaves', International Journal of Pharmacy Teaching \& Practices, Vol.2, no.3, pp. 129 -132.

[19]. Bibekananda Mohanty, Partha Datta, B. Dasgupta1 \& Dalim Kumar Sengupta 2011, 'Integrated Management of Foot and Leaf Rot of Betelvine', SAARC Journal of Agriculture, Vol.9, no.2, pp. 83 -91.

[20]. Bindu Tiger \& Toran Verma 2013, 'Identification and Classification of Normal and Infected Apples using Neural Network', International Journal of Science and Research, Vol.2, no.6, pp. 160 -163.

[21]. Burks T.F, A. Shearer S.A, \& Payne F.A 2010, 'Classification of Weed Species Using Color Texture Features And Discriminant Analysis', American Society of Agricultural Engineers', Vol.43, no.2, pp.441-448.

[22]. P. Chowdappa,D. Brayford,J. Smith \& J. Flood 2003, 'Identification of Phytophthora species affecting plantation crops by RFLP of PCR-amplified internal transcribed spacer regions of ribosomal RNA', Current Science, Vol.85, no.1, pp. $34-36$.

[23]. Diao Zhihua, Wang Huan, Song Yinmao \& Wang Yunpeng 2013, 'Image Segmentation Method for Cotton Mite Disease Based on Color Features and Area Thresholding', Journal of Theoretical and Applied Information Technology, Vol.48, no.1, pp. $527-533$.

[24]. B. Dasgupta, B.Mohanty, P. K. DUTTA \& Satyabrata Maiti 2008, 'Phytophthora Diseases of Betelvine (Piper Betle L.) - A Menace To Betelvine Crop', SAARC Journal of Agriculture, Vol.6, no.1, pp. 1 -19.

[25]. Debabrata Samanta \& Arya Ghosh 2012, 'Histogram Approach for Detection of Maize Leaf Damage', International Journal of Computer Science and Telecommunications, Vol. 3, no. 2, pp. 26-28.

[26]. Dinesh Chandra Khatua, Bholanath Mondal \& Rana Bhattachayya 2013, 'A selective medium for Xanthomonas axonopodis pv. Betlicola, bacterial pathogen of betelvine', African Journal of Agricultural Research, Vol.8, no.49, pp. $6388-6393$.

[27]. Faithpraise Fina, Philip Birch, Rupert Young, J. Obu, Bassey Faithpraise \& Chris Chatwin 2013, 'Automatic Plant Pest Detection and Recognition Using K-Means Clustering Algorithm and Correspondence Filters', International Journal of Advanced Biotechnology and Research, Vol.4, no.2, pp. 189 -199.

[28]. A. R. Fathilah 2011, 'Piper betle L. and Psidium uajava L. in oral health maintenance' Journal of Medicinal Plants Research, Vol.5, no.2, pp. $156-163$.

[29]. Faisal Ahmed, Hasanul Kabir, Shayla Bhuyan, Hossain Bari \& Emam Hossain 2014, 'Automated Weed Classification with Local Pattern-Based Texture Descriptors', The International Arab Journal of Information Technology, Vol.11, no.1, pp.87-94.

[30]. Faisal Ahmed, A.S.M. Hossain Bari, Emam Hossain, Hawlader Abdullah Al-Mamun \& Paul Kwan 2011, 'Performance Analysis of Support Vector Machine and Bayesian Classifier for Crop and Weed Classification from Digital Images', World Applied Sciences Journal, Vol.12, no.4, pp.432-440.

[31]. Gayatri Vijay Patil Pranali vivekanand More, Nandinee Dattatrey Pawar 2014, 'SVM approach for color image classification using shape and texture', International Journal of Emerging Trends in Engineering and Development, Vol.3, no.4, pp. 139 - 146. 
[32]. J. L. Gonzalez-Perez, M. C. Espino-Gudino, J. Gudino-Bazaldua, J. L. Rojas-Renteria, V. RodriguezHernandez \& V.M. Castano 2013, 'Color image segmentation using perceptual spaces through applets for determining and preventing diseases in chili peppers', African Journal of Biotechnology, Vol.12, no.7, pp. $679-688$.

[33]. P. Guha 2006, 'Betel Leaf: The Neglected Green Gold of India', Journal of Human Ecology, Vol.19, no.2, pp. $87-93$.

[34]. B. K. Goswamil, K. A. Kader, M. L. Rahman, M. R. Islam \& P. K. Malaker 2002, 'Development of Leaf Spot of Betel Vine Caused By Colletotrichum Capsici', Bangladesh Journal of Plant Pathology, Vol.18, no.1, pp. $39-41$.

[35]. Guillaume Cerutti,Laure Tougneb, Julien Mille, Antoine Vacavant \& Didier Coquin 2013, 'Understanding Leaves in Natural Images -A Model-Based Approach for Tree Species Identification' Computer Vision and Image Understanding, Vol.117, no.10, pp. 1482 - 1501.

[36]. V. A. Gulhane \& A. A. Gurjar 2011, 'Detection of Diseases on Cotton Leaves and Its Possible Diagnosis', International Journal of Image Processing, Vol.5, no.5, pp. 590-598.

[37]. M I. Huq 2011, 'Studies on the Epidemiology of Leaf Rot and Leaf Spot Diseases of Betel Vine (Piper Betle L.)', Bangladesh Journal of Scientific and Industrial Research, Vol.46, no.4, pp. 519 -522.

[38]. Hong Fang \& Huijie Li 2014, 'Plant Leaves Recognition and Classification Model Based on Image Features and Neural Network', IJCSI International Journal of Computer Science, Vol.11, no.1, pp. 100 - 104.

[39]. Hrishikesh P. Kanjalkar \& S.S.Lokhande 2014,'Feature Extraction of Leaf Diseases', International Journal of Advanced Research in Computer Engineering \& Technology, Vol.3, no.1, pp. 153 -155.

[40]. Jagadeesh Devdas Pujari, Rajesh Yakkundimath \& Abdulmunaf Syedhusain Byadgi 2013, 'Grading and Classification of Anthracnose Fungal Disease of Fruits based on Statistical Texture Features', International Journal of Advanced Science and Technology, Vol.52, no.1, pp. 121 -132.

[41]. Jayamala K. Patil \& Raj Kumar 2011, 'Advances In Image Processing for Detection of Plant Diseases', Journal of Advanced Bioinformatics Applications and Research, Vol.2, no.2, pp.135-141.

[42]. Junlong Fang, Shuwen Wang \& Changli Zhang 2005, 'Application of Genetic Algorithm (GA) Trained Artificial Neural Network to Identify Tomatoes with Physiological Diseases', Nature and Science, Vol.3, no.2, pp.1-7.

[43]. V. V. Kaleeswari \& T.Sridhar 2013, 'A Study on Betel Vine Cultivation and Market Crisis in Karur District', Indian Journal of Applied Research Vol. 3, no. 10, pp. 1-3.

[44]. Kiran. R, Gavhale \& Ujwalla Gawande 2014, 'An Overview of the Research on Plant Leaves Disease detection using Image Processing Techniques', IOSR Journal of Computer Engineering, Vol.16, no.1, pp. $10-16$.

[45]. Lakshmi Arambewela,K,G.A. Kumarratunga \& Kalyani Dias 2005, 'Studies of Piper Betle of Sri Lanka', Journal of the National Science Foundation of Sri Lanka, Vol.33, no.2, pp. 133 -139.

[46]. Manoj P Rai, Karadka Ramdas Thilakchand, Princy L Palatty, Prathima Rao, Suresh Rao, Harshith P Bhat \& Manjeshwar Shrinath Baliga 2011, 'Piper Betel Linn (Betel Vine), the Maligned Southeast Asian Medicinal Plant Possesses Cancer Preventive Effects: Time to Reconsider the Wronged Opinion', Asian Pacific Journal of Cancer Prevention, Vol.12, no.1, pp. 2149 -2156. 
J.Vijayakumar \& Dr. S.Arumugam; Powdery Mildew Disease Identification in Karpoori Variety of Betel vine Plants using Histogram Based Techniques, Advances in Image and Video Processing, Volume 2 No 5, Oct (2014); pp: $63-75$

[47]. Manoj Mukherjee, Titan Pal \& Debabrata Samanta 2012, 'Damaged Paddy Leaf Detection Using Image Processing', Journal of Global Research in Computer Science, Vol.3, no.10, pp. 7-10.

[48]. Maliheh Shabanzade, Morteza Zahedi \& Seyyed Amin Aghvami 2011, 'Combination of Local Descriptors And Global Features For Leaf Recognition', Signal \& Image Processing : An International Journal, Vol.2, no.3, pp. $23-31$.

[49]. Mokhled S. Al-Tarawneh 2013, 'An Empirical Investigation of Olive Leave Spot Disease Using AutoCropping Segmentation and Fuzzy C-Means Classification' World Applied Sciences Journal, Vol.23, no.9, pp. $1207-1211$.

[50]. Manpreet Kaur, Jasdeep Kaur \& Jappreet Kaur 2011, 'Survey of Contrast Enhancement Techniques based on Histogram Equalization', International Journal of Advanced Computer Science and Applications, Vol.2, no.7, pp.137-141.

[51]. Mohamad Faizal Ab Jabal, Suhardi Hamid, Salehuddin Shuib \& Illiasaak Ahmad 2013, 'Leaf Features Extraction and Recognition Approaches to Classify Plant', Journal of Computer Science, Vol.9, no.10, pp.1295-1304.

[52]. Madhuri V \& Amrutha Gayathri D 2014, 'Root Rot of Chilli Incited By Sclerotium Rolfsii Sacc. And Its Management- A Review', International Journal of Applied Biology and Pharmaceutical Technology, Vol.5, no.1, pp.197-204.

[53]. Manimekalai .K \& Vijaya.MS 2014, 'Support Vector Machine Based Tool For Plant Species Taxonomic Classification', Journal of Asian scientific research, Vol.4, no.4, pp.159-173.

[54]. T. Nalina \& Z.H.A. Rahim 2007, 'The Crude Aqueous Extract of Piper betle L. and its Antibacterial Effect Towards Streptococcus mutans', American Journal of Biotechnology and Biochemistry, Vol.3, no.5, pp. 10 -15 .

[55]. Narendra V G \& Hareesh K S 2010, 'Prospects of Computer Vision Automated Grading and Sorting Systems in Agricultural and Food Products for Quality Evaluation', International Journal of Computer Applications, Vol.1, no.4, pp.1-9.

[56]. Narendra V G \& Hareesh K S 2010, 'Quality Inspection and Grading of Agricultural and Food Products by Computer Vision- A Review', International Journal of Computer Applications, Vol.2, no.1, pp.43-65.

[57]. Nitin S. Tijare \& Sagar S. Badnerkar 2014, 'Image Recognition Based Crop Disease Identification System: A Survey', International Journal of Computer Science and Mobile Computing, Vol.3, no.4, pp.868-873.

[58]. Namita Mittal, Basant Agarwal, Ajay Gupta \& Hemant Madhur 2014, 'Icon Based Information Retrieval and Disease Identification in Agriculture', International Journal of Advanced Studies in Computer Science \& Engineering, Vol.3, no.3, pp. 26 - 31.

[59]. Pranjali Vinayak Keskar, Shubhangi Nimba Masare, Manjusha Suresh Kadam \& Seema U.Deoghare 2013, 'Leaf Disease Detection and Diagnosis', International Journal of Emerging Trends in Electrical and Electronics, Vol.2, no.2, pp. 28 - 31.

[60]. S. R. Pokharkar \& V. R.Thool 2012, 'Early Pest Identification in Greenhouse Crops using Image Processing Techniques', International Journal of Computer Science and Network, Vol.1, no.3, pp. 1-6. 
[61]. S. Phadikar, J. Sil \& A. K. Das 2012, 'Classification of Rice Leaf Diseases Based on Morphological Changes, International Journal of Information and Electronics Engineering, Vol.2, no.3, pp. 460-463

[62]. K. Padmavathi 2012, 'Investigation and monitoring for leaves disease detection and evaluation using image processing' International Research Journal of Engineering Science, Technology and Innovation, Vol.1, no.3, pp. 66-70.

[63]. Piyush Chaudhary, Anand K. Chaudhari,A. N. Cheeran\& Sharda Godara 2012, 'Color Transform Based Approach for Disease Spot Detection on Plant Leaf', International Journal of Computer Science and Telecommunications, Vol.1, no.6, pp. $65-70$.

[64]. Pradnya Ravindra Narvekar, Mahesh Manik Kumbhar \& S. N. Patil 2013, 'Grape Leaf Diseases Detection \& Analysis using SGDM Matrix Method', International Journal of Innovative Research in Computer and Communication Engineering. Vol.2, no.3, pp. 3365 - 3372.

[65]. Qinghai He, Benxue Ma, Duanyang Qu, Qiang Zhang,Xinmin Hou \& Jing Zhao 2013, 'Cotton Pests and Diseases Detection based on Image Processing',Telkomnika Indonesian Journal of Electrical Engineering, Vol.11, no.6, pp. 3445 - 3450.

[66]. Rafiqul Haider.M,Abul Khair,M.Mahfuzur Rahman \& M.Khairul Alam 2013, 'Indigenous Management Practices of Betel-Leaf (Piper Betle L.) Cultivation by the Khasia community in Bangladesh' Indian journal of Traditional knowledge, Vol.12, no.2, pp. 231 -239.

[67]. Rupesh G. Mundada \& V. V. Gohokar 2013, Detection and Classification of Pests in Greenhouse Using Image Processing', IOSR Journal of Electronics and Communication Engineering, Vol.5, no.6, pp. 57-63.

[68]. Rothe P.R \& Kshirsagar R.V 2014, 'SVM-based Classifier System for Recognition of Cotton Leaf Diseases', International Journal of Emerging Technologies in Computational and Applied Sciences, Vol.7, no.4, pp. $427-432$.

[69]. Rama M \& Syama Sundar B 2013, 'The Comparison of Antioxidative And Antimicrobial Properties of Leaf Extracts of Ocimum Gratissimum, Pimenta Dioica And Piper Betel', International Journal of Chemical And Pharmaceutical Research, Vol.2, no.1, pp.1-14.

[70]. Savita N. Ghaiwat 2014, 'Detection and Classification of Plant Leaf Diseases Using Image processing Techniques: A Review’ Vol.2, no.3, pp. 2347 - 2812.

[71]. Safikul Alam.SK, Sourabh Chandra \& Debabrata Samanta 2014, 'Automated Damaged Ginkgo Leaf Detection', International Journal of Advanced Research in Computer and Communication Engineering, Vol.3, no.1, pp. 5233 - 5236.

[72]. Sabah Bashir \& Navdeep Sharma 2012,'Remote Area Plant Disease Detection Using Image Processing', IOSR Journal of Electronics and Communication Engineering, Vol.1, no.6, pp. 31-34.

[73]. Sanjeev S Sannakki, Vijay S Rajpurohit, V B Nargund, Arun Kumar R \& Prema S Yallur 2011,'Leaf Disease Grading by Machine Vision and Fuzzy Logic', International Journal of Computer Technology and Applications, Vol. 2, no.5, pp. 1709-1716.

[74]. Sanjay B. Patil \& Shrikant K. Bodhe 2011,'Leaf Disease Severity measurement Using Image Processing', International Journal of Engineering and Technology, Vol.3, no.5, pp. 297-301.

[75]. Sitaram Longani, Prof.V.V. Dixit 2013, 'Pest Detection on Leaves Using Poission's Thresholding Techniques', The International Journal Of Engineering And Science, Vol.3, no.10, pp. 6-10. 
[76]. Sumathi.C.S \& A. V. Senthil Kumar 2014, 'Enhancing Accuracy of Plant Leaf Classification Techniques', International Journal of Engineering Research and Applications, Vol.4, no.3, pp. 40 - 46.

[77]. Sanjay B. Dhaygude \& Nitin P.Kumbhar 2013, 'Agricultural plant Leaf Disease Detection Using Image Processing', International Journal of Advanced Research in Electrical, Electronics and Instrumentation Engineering, Vol.1, no.2, pp. $599-602$.

[78]. Shweta Tyagi \& Hemant Amhia 2013, 'Image Enhancement and Analysis of Thermal Images Using Various Techniques of Image Processing', International Journal of Engineering Research and Applications, Vol.2, no.3, pp. $579-584$.

[79]. Smita Naikwadi \& Niket Amoda 2013, 'Advances In Image Processing for

[80]. Detection of plant diseases', International Journal of Application or Innovation in Engineering \& Management, Vol.2, no.11, pp. $168-175$.

[81]. Shital Bankar, Ajita Dube,Pranali Kadam \& Sunil Deokule 2014, 'Plant Disease Detection Techniques Using Canny Edge Detection \& Color Histogram in Image Processing', International Journal of Computer Science and Information Technologies, Vol.52, no.2, pp. 1165 - 1168.

[82]. Suneetha.I \& Venkateswarlu.T 2012, 'Enhancement Techniques for Gray scale Images in Spatial Domain', International Journal of Emerging Technology and Advanced Engineering, Vol.2, no.4, pp. 13 - 20.

[83]. Smita Patil, Shridevi Soma \& Suvarna Nandyal 2013, 'Identification of Growth Rate of Plant based on leaf features using Digital Image Processing Techniques', International Journal of Emerging Technology and Advanced Engineering, Vol.3, no.8, pp. 266 - 275.

[84]. Somasundaram Devaraj, V. R. Vijaykumar, Godwin Raj Soundrarajan, Sengottaiyan \& Narmada 2013, 'Leaf Biometrics Based Karyotyping of G-Band Chromosomes' International Journal of Human Genetics, Vol.7, no.4, pp.131-138.

[85]. Sandeep Kumar.E 2012, 'Leaf Color, Area and Edge Features Based Approach For Identification af Indian Medicinal Plants', Indian Journal of Computer Science and Engineering, Vol.3, no.3, pp.436-442.

[86]. Sudheer Reddy Bandi, Varadharajan A \& A Chinnasamy 2013, 'Performance Evaluation of Various Statistical Classifiers In Detecting The Diseased Citrus Leaves', International Journal of Engineering Science and Technology, Vol.5, no.2, pp.298-307.

[87]. Sulochana Wadhwani, A.K.Wadhwani, Monika Saraswat 2013, 'Classification of Breast Cancer Detection Using Artificial Neural Networks', Current Research in Engineering, Science and Technology Journals. Vol.1, no.3, pp.85-91.

[88]. J.D. Sharma, Lalita Sharma \& Poonam Yadav 2007, 'Antifertility Efficacy of Piper betle Linn. (Petiole) on Female Albino Rats', Asian Journal of Experimental Sciences, Vol.21, no.1, pp. 145 -150.

[89]. B. Seetha Lakshmi \& K. C. Naidu 2010, 'Comparative Morphoanatomy of Piper betle L. cultivars in India', Annals of Biological Research, Vol.1, no.2, pp. 128 -134.

[90]. Saleem Shahzad \& Amer Zareen 1999, 'Leaf spot of Betelvine in Pakistan, Pakistan Journal of Botany, Vol.31, no.2, pp. $437-443$. 
[91]. B. C. Sarker, S. K. Adhikary, S. Sultana, A. Biswas \& S. F. D. Azad 2013, 'Influence of pH on Growth and Sclerotia Formation of Sclerotium rolfsii Causal Agent of Foot Rot Disease of Betel Vine', IOSR Journal of Agriculture and Veterinary Science, Vol.4, no.1, pp. $67-70$.

[92]. A. Tripathi, R. Singh, S. K. Raj, A. P. Singh \& J. K. Johri 2003, 'Molecular Identification of Phytophthora Nicotianae Isolates Causing Leaf Rot of Betelvine (Piper Betle L.)', Current Science, Vol.84, no.1, pp. 22 24.

[93]. Viraj A. Gulhane \& Ajay A. Gurjar 2011, 'Detection of Diseases on Cotton Leaves and Its Possible Diagnosis', International Journal of Image Processing, Vol.5, no.5, pp. 590 -598.

[94]. Vinod Kumar \& Rahul Raj Choudhary 2012, 'A Comparative Analysis of Image Contrast Enhancement Techniques based on Histogram Equalization for Gray Scale Static Images', International Journal of Computer Applications, Vol.45, no.21, pp.11-15.

[95]. J.Vijayakumar \& Dr.S.Arumugam 2012, 'Study of Betelvine Plants Diseases and Methods of Disease Identification using Digital Image Processing', European Journal of Scientific Research, Vol.70, no.2, pp.240-244.

[96]. J.Vijayakumar \& Dr.S.Arumugam 2012, 'Recognition of Powdery Mildew Disease for Betelvine Plants Using Digital Image Processing' International Journal of Distributed and Parallel Systems, Vol.3, no.2, pp.231-241.

[97]. J.Vijayakumar \& Dr.S.Arumugam 2011, 'Foot Rot Disease Identification for the Betelvine Plants using Digital Image Processing', Journal of Computing, Vol. 3, no 2, pp.180-183.

[98]. J.Vijayakumar \& Dr.S.Arumugam 2012, 'Early detection of powdery mildew disease for Betelvine plants using digital image analysis', International Journal of Modern Engineering Research, Vol.2, no.4, pp. 25812583.

[99]. J.Vijayakumar \& Dr.S.Arumugam 2012, 'Powdery Mildew Disease Identification for Vellaikodi Variety of Betelvine Plants using Digital Image Processing', European Journal of Scientific Research, Vol.88, no.3, pp.409-415.

[100]. J.Vijayakumar \& Dr.S.Arumugam 2012, ‘Foot Rot Disease Identification for Vellaikodi Variety of Betelvine Plants using Digital Image Processing', ICTACT Journal on Image And Video Processing, Vol.3, no.2, pp.495-501.

[101]. J.Vijayakumar \& Dr.S.Arumugam 2013, 'Disease Identification in Pachaikodi Variety of Betelvine Plant Using Digital Imaging Techniques', Archives Des Sciences, Vol.66, no.1, pp.308-312.

[102]. J.Vijayakumar \& Dr.S.Arumugam 2013, 'Foot Rot Disease Identification for Karpoori variety of Betelvine Plants Using Digital Imaging Technique' Australian Journal of Basic and Applied Sciences, Vol.7, no.11, pp.270-274.

[103]. J.Vijayakumar \& Dr.S.Arumugam 2014, ‘Odium Piperis Fungus Identification for Piper Betel Plants Using Digital Image Processing', Journal of Theoretical and Applied Information Technology, Vol.60, no.2, pp.423-427. 